\title{
Numerical Investigation of the Combustion Kinetics of Partially Premixed Combustion (PPC) Fueled with Primary Reference Fuel
}

\begin{abstract}
This work numerically investigates the detailed combustion kinetics of partially premixed combustion (PPC) in a diesel engine under three different premixed ratio fuel conditions. A reduced Primary Reference Fuel (PRF) chemical kinetics mechanism was coupled with CONVERGE-SAGE CFD model to predict PPC combustion under various operating conditions. The experimental results showed that the increase of premixed ratio (PR) fuel resulted in advanced combustion phasing. To provide insight into the effects of PR on ignition delay time and key reaction pathways, a post-process tool was used. The ignition delay time is related to the formation of hydroxyl $(\mathrm{OH})$. Thus, the validated Converge CFD code with the PRF chemistry and the post-process tool was applied to investigate how PR change the formation of $\mathrm{OH}$ during the low-to high-temperature reaction transition.
\end{abstract}

The reaction pathway analyses of the formations of $\mathrm{OH}$ before ignition time were investigated. It was found that in the case of PR0\%, the second isomerization from $\mathrm{C}_{7} \mathrm{H}_{14} \mathrm{OOH}_{2}-4 \mathrm{O}_{2}$ to NC7KET24 and the decomposition of NC7KET24 contributed $27.6 \%$ and $46.46 \%$ of $\mathrm{OH}$ formation respectively. The contribution of $\mathrm{AC}_{8} \mathrm{H}_{16} \mathrm{OOH}-\mathrm{B}$ to the formation of $\mathrm{OH}$ was just $12.13 \%$. It can be concluded that the low temperature oxidation reactions of n-heptane were key steps in producing $\mathrm{OH}$. While in the cases of PR30\% and PR50\%, because of the higher in-cylinder temperature, most of $\mathrm{OH}$ derived from the decomposition reaction of $\mathrm{H}_{2} \mathrm{O}_{2}$ that contributed $54.47 \%$ and $54.63 \%$ of $\mathrm{OH}$ formation respectively. Besides, in the PR $30 \%$ and PR50\%, the oxidation reactions of $\mathrm{IC}_{4} \mathrm{H}_{7}$ contributed $31.95 \%$ and $33.84 \%$ of $\mathrm{OH}$ formation respectively, and the oxidation reaction of $\mathrm{IC}_{4} \mathrm{H}_{6} \mathrm{OH}$ contributed $19.08 \%$ and $22.22 \%$ of $\mathrm{OH}$ formation respectively, which indicated that the oxidation of iso-octane also contributed to the production of $\mathrm{OH}$. In addition, the distributions of mass fraction, production rate and representative creation reaction (RCR) of $\mathrm{OH}$ showed that in the case of PR $30 \%$ and PR50\%, the formation of $\mathrm{OH}$ outside the spray periphery were dominated by the reactions R394 $(\mathrm{H} 2 \mathrm{O} 2(+\mathrm{M}) \Leftrightarrow 2 \mathrm{OH}(+\mathrm{M}))$, while that in the spray periphery were predominantly controlled by the reaction R21 (NC7KET24 $\Rightarrow$ $\mathrm{NC} 3 \mathrm{H} 7 \mathrm{CHO}+\mathrm{CH} 3 \mathrm{COCH} 2+\mathrm{OH})$ and $\mathrm{R} 125\left(\mathrm{IC}_{4} \mathrm{H}_{6} \mathrm{OH}+\mathrm{HO}_{2} \longleftrightarrow \Rightarrow\right.$ $\mathrm{CH}_{2} \mathrm{CCH}_{2} \mathrm{OH}+\mathrm{CH}_{2} \mathrm{O}+\mathrm{OH}$ ). Premixed fuel from port injection changed the formation pathway of $\mathrm{OH}$ during the oxidation of direct injection fuel through the reaction R125.

\section{Introduction}

Internal combustion engines are the one of major consumers of oil. With the fossil fuels being depleted, more stringent regulations have been mandated to limit fuel economy, the carbon dioxide $\left(\mathrm{CO}_{2}\right)$ emission, and some other harmful gas emissions. In the past decades, in order to achieve clean and high-efficiency combustion, some novel combustion concepts have been proposed, such as low temperature combustion (LTC) [1], homogeneous charge compression ignition (HCCI) [2]. HCCI mode which provides a homogeneous charge for compression ignition, has drawn worldwide attention due to its advantages in terms of high thermal efficiency and low soot and NOx emissions, but it also meets with issues of the homogeneous fuel mixture preparation, high pressure rise rate and load extension, combustion phasing control and high HC (hydrocarbon) as well as carbon oxide (CO) emissions [2]. Generally, both HCCI and LTC have the compromise between emissions and operating range $[3,4]$.

With the deepening understanding on HCCI combustion, it was found that the absolutely homogeneous charge is infeasible to be organized, and inhomogeneity in concentration and temperature must exist in HCCI combustion process $[5,6,7,8]$. Moreover, the inhomogeneity in compression ignition engine are beneficial to control the combustion phasing and extend the range of operating conditions to some extent $[9,10]$. Based on the previous research on HCCI and LTC, PPC [11, $12]$ and premixed charge compression ignition (PCCI) $[13,14]$ have been proposed to cope with the aforementioned challenges faced by HCCI and LTC $[15,16]$. The PPC and PPCI mode adopt controllable stratified charge prior to ignition by only direct fuel injection in the cylinder rather than homogeneous charge in HCCI. The reasonable concentration stratification of the charge in the cylinder can control combustion phasing well $[17,18]$. Besides, according to different operating conditions, the fuel concentration stratification can be modulated by adjusting the injection timing of the fuel, thus the heat release rate can be effectively controlled. For example, Dec [19] designed fuel concentration stratification by premixing most of the fuel with intake air during the intake stroke and direct injecting the rest of the fuel during the compression stroke. It was found that staged combustion can be achieve by fuel stratification, which can effectively reduce the maximum pressure rising rate and is beneficial for the expansion of high load.

The concentration stratification of charge in the cylinder can be controlled by fuel injection strategy, such as different injection timings and multiple injection strategy [20, 21, 22, 23], combination of port injection and multiple injection strategy [24, 25, 26, 27, 28], and so on. For instance, a double-injection strategy has shown the independent control of mixture homogeneity of the early first injection and charge stratification of the late second injection, which cause a lower rate of pressure rise, extended high-load limit, and better combustion stability $[29,30,31,32]$. A compound injection strategy with port- and direct injection can flexibly adapt to the change of load by adjusting the 
premixed ratio of fuel [33, 34]. For example, Liu et al. [33] shows that with the decrease of the premixed ratio, the peak heat release rate decreases, combustion phasing delays, and the thermal efficiency show the tendency of first decreasing and then increasing. However, although the mixture homogeneity enhanced by the strategies of double injection and compound injection contributes to suppressed thermal NO and soot formation simultaneously, the unburned hydrocarbon (HC) and $\mathrm{CO}$ emissions are higher. In general, numerous researchers have investigated the engine performance and emissions of PPC mode [35, 36, 37] from which a good understanding of thermal efficiency and engine-out emission trends has been developed.

To provide insight into fundamentals of the combustion, optical diagnostic techniques have provided an efficient means by which direct investigate the engine spray, combustion and the evolution of key species. For instance, Tang et al. [38] showed that the variation of the fuel stratification degree caused by the different fuel injection timings is responsible for this transformation in the flame development pattern for gasoline PPC. Harsh et al. [39] took focus on how the ignition occurs during the low- to high-temperature reaction transition and how it varies due to single- and double-injection strategies. Their experimental investigation showed that in the case of double-injection gasoline PPC combustion, during the low- to high-temperature reaction transition, the $\mathrm{HCHO}$ consumption to form $\mathrm{OH}$ radicals is higher, indicating faster transition for better combustion stability. However, the optical engine observations only focused on a number of specific species, making it difficult to fully clarify the engine combustion details [40, 41, 42, 43].

On the other hand, the computational fluid dynamics (CFD) model coupled with chemical kinetics mechanism has been well known as a powerful tool to investigate the PPC combustion and emission formation processes [44, 45, 46]. For example, Dempsey et al. [47] compared three mixture stratification (partial, moderate and heavy stratifications) on the PPC combustion numerically. The results demonstrated that there was a trade-off between fuel stratification and combustion efficiency, and the heavy mixing case would have higher soot tendency. More recently, Liu et al. [48] showed that the gasoline PPC combustion was initiated by the spray periphery near the cylinder bowl, and NOx was mainly formed in the spray periphery rather than the homogeneous region, while soot was formed in the downstream of the spray. According to literature research, obviously, the past analysis of 3D CFD simulation of PPC combustion focused mainly on the spatial distribution of important parameters, such as temperature and key species. However, the detailed combustion chemical kinetics process, such as the instantaneous species destruction pathway, in a CFD model is very limited. Additionally, the research about the effects of different premixed ratio fuel on combustion kinetics in PPC combustion has not been reported before.

Therefore, in the current study, a CFD modeling coupled with incylinder reaction pathway analysis to investigate the ignition delay characteristics of three different PR engine operating in the PPC combustion mode. A post-processing method developed by Liu [43, 49] is able to carry out reaction pathway analysis by integrating over the corresponding computational domains. This method is primarily coded in the MATLAB environment. More details about the method can be found in literature $[43,49]$. The fidelity of the method has been Page 2 of 11 verified by CHEMKIN results, which proves that the method is able to well capture the combustion details.

This work is an attempt to further study the effects of premixed fuel on the fuel combustion of PPC computationally, characterized by both port injection and direct injection on a single-cylinder CI engine. More specifically, the objective of the current study is to explore the function of different PR on the ignition delay of PPC combustion and advance our understanding of the combustion kinetics interaction between premixed fuel and direct injection fuel.

Following the introduction section that provide a detailed literature review and the objective of this research, a section is provided to introduce the experimental and modeling setup, combustion visualization method and modeling validation. Then the paper discusses and analyzes the simulation results, aiming at the ignition delay under three different PR in a CI engine, the creation reaction pathway of $\mathrm{OH}$, the spatial distribution of $\mathrm{OH}$ in cylinder during the combustion process. Finally, conclusions are provided.

\section{Experiment and modeling setup}

\section{Experimental Setup}

All the PPC combustion experiments with primary reference fuel (70\% isooctane and $30 \%$ n-heptane, PRF70) were conducted in a single cylinder, 4-stroke, 4-valve diesel engine, which was modified from a six-cylinder engine with the other 5 cylinders unchanged. The schematic diagram of the experimental setup is shown in Figure 1, and the engine specifications are listed in Table 1. The detailed information about the measurement instruments can be referred in the refs. [28].

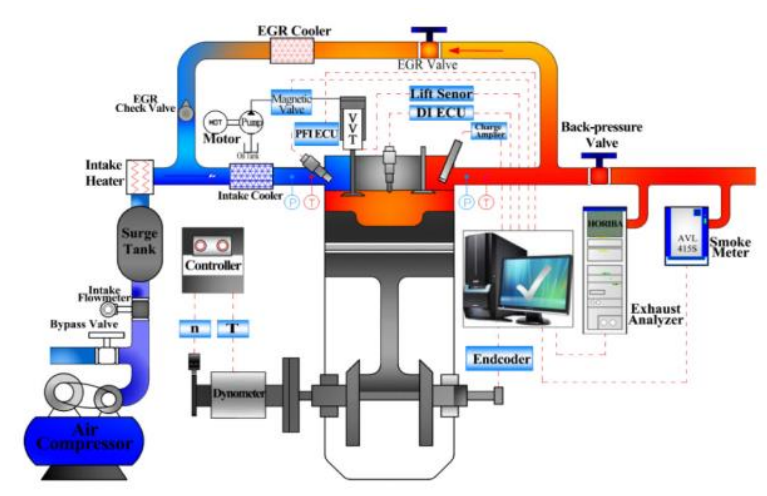

Figure 1. Schematic of experimental setup

As shown in Figure 1, an air compressor was used to simulate the intake boost pressure. A back-pressure valve was used to regulate the EGR rate. The intake port injector (Delphi) was used to control the premixed fuel distribution, and the common rail injector (Bosch) in the cylinder head was used to control the direct-injection fuel distribution. The in-cylinder pressure was measured by a piezoelectric transducer (Kistler 6125C01U20). For each operating point, the in-cylinder pressures of 100 engine cycles were collected. The fuel flow rates of intake-port injection and direct injection were measured by two fuel consumption meters (AVL 733S) respectively. Soot emission was measured by a filter smoke meter (AVL 415S), while HC, CO and NOx emissions were measured by a gas analyzer (Horiba MEXA7100DEGR). 
Table 1. Engine specifications

\begin{tabular}{|l|l|}
\hline Engine Type & $\begin{array}{l}\text { Modified single cylinder heavy-duty } \\
\text { diesel engine }\end{array}$ \\
\hline Displacement & $1.0818 \mathrm{~L}$ \\
\hline Bore /stroke & $105 / 125 \mathrm{~mm}$ \\
\hline Connecting rod length & $210 \mathrm{~mm}$ \\
\hline IVC & $-133 \mathrm{CA}$ ATDC \\
\hline EVO & $125 \mathrm{CA}$ ATDC \\
\hline Compression ratio & $16: 1$ \\
\hline Port fuel injector & $\begin{array}{l}4 \text { holes, injection angle } 15^{\circ}, \text { injection } \\
\text { pressure } 0.3 \mathrm{MPa}\end{array}$ \\
\hline Common rail injector & $\begin{array}{l}8 \text { holes, injection angle } 150^{\circ}, \text { injection } \\
\text { pressure } 80 \mathrm{MPa}, 0.15 \mathrm{~mm} \text { nozzle }\end{array}$ \\
\hline Swirl number & 1.2 \\
\hline
\end{tabular}

Table 2. Engine operating conditions.

\begin{tabular}{|l|l|l|l|}
\hline Parameters & Case1 & Case2 & Case3 \\
\hline Engine speed (rpm) & 1500 & 1500 & 1500 \\
\hline Total injection mass (mg/cyc) & 32 & 32 & 32 \\
\hline SOI (CA ATDC) & -9 & -9 & -9 \\
\hline Premixed ratio (\%) & 0 & 30 & 50 \\
\hline Duration of direct injection (CA) & 15.1 & 11.9 & 8.7 \\
\hline Intake air pressure (bar) & 1.8 & 1.8 & 1.8 \\
\hline Intake air temperature $\left({ }^{\circ} \mathrm{C}\right)$ & 50 & 50 & 50 \\
\hline EGR rate $(\%)$ & 45 & 45 & 45 \\
\hline
\end{tabular}

Table 3. list of the key RCR reactions.

\begin{tabular}{|c|c|}
\hline R5 & $\mathrm{NC} 7 \mathrm{H} 16+\mathrm{O}=>\mathrm{C} 7 \mathrm{H} 15-2+\mathrm{OH}$ \\
\hline R20 & $\mathrm{C} 7 \mathrm{H} 14 \mathrm{OOH} 2-4 \mathrm{O} 2<=>\mathrm{NC} 7 \mathrm{KET} 24+\mathrm{OH}$ \\
\hline R21 & NC7KET24 $\Rightarrow>\mathrm{NC} 3 \mathrm{H} 7 \mathrm{CHO}+\mathrm{CH} 3 \mathrm{COCH} 2+\mathrm{OH}$ \\
\hline R22 & $\mathrm{C} 7 \mathrm{H} 14 \mathrm{OOH} 2-4=>\mathrm{OH}+\mathrm{CH} 3 \mathrm{CHO}+\mathrm{C} 5 \mathrm{H} 10$ \\
\hline R31 & $\mathrm{IC} 8 \mathrm{H} 18+\mathrm{O}=>\mathrm{AC} 8 \mathrm{H} 17+\mathrm{OH}$ \\
\hline R40 & AC8H16OOH-B $\Rightarrow$ IC8ETERAB + OH \\
\hline R43 & AC8H16OOH-BO2 $\Leftrightarrow=$ IC8KETAB + OH \\
\hline R46 & $\mathrm{IC} 8 \mathrm{KETAB}=>\mathrm{IC} 3 \mathrm{H} 7 \mathrm{CHO}+\mathrm{TC} 3 \mathrm{H} 6 \mathrm{CHO}+\mathrm{OH}$ \\
\hline R97 & $\mathrm{TC} 3 \mathrm{H} 6 \mathrm{O} 2 \mathrm{HCO}<=>\mathrm{CH} 3 \mathrm{COCH} 3+\mathrm{CO}+\mathrm{OH}$ \\
\hline R108 & $\mathrm{IC} 4 \mathrm{H} 7+\mathrm{HO} 2 \Rightarrow \mathrm{IC} 4 \mathrm{H} 7 \mathrm{O}+\mathrm{OH}$ \\
\hline R112 & $\mathrm{IC} 4 \mathrm{H} 7+\mathrm{O} 2 \Leftrightarrow \mathrm{C} 3 \mathrm{H} 4+\mathrm{CH} 2 \mathrm{O}+\mathrm{OH}$ \\
\hline R125 & $\mathrm{IC} 4 \mathrm{H} 6 \mathrm{OH}+\mathrm{HO} 2 \Leftrightarrow \Rightarrow \mathrm{CH} 2 \mathrm{CCH} 2 \mathrm{OH}+\mathrm{CH} 2 \mathrm{O}+\mathrm{OH}$ \\
\hline R165 & $\mathrm{C} 3 \mathrm{KET} 21 \Leftrightarrow \mathrm{CH} 2 \mathrm{O}+\mathrm{CH} 3 \mathrm{CO}+\mathrm{OH}$ \\
\hline R178 & $\mathrm{C} 3 \mathrm{H} 5+\mathrm{HO} 2 \Leftrightarrow=>\mathrm{OH}+\mathrm{C} 2 \mathrm{H} 3+\mathrm{CH} 2 \mathrm{O}$ \\
\hline R224 & $\mathrm{C} 2 \mathrm{H} 5+\mathrm{O} 2 \Rightarrow \mathrm{CH} 3 \mathrm{CHO}+\mathrm{OH}$ \\
\hline R282 & $\mathrm{CH} 2 \mathrm{CHO}+\mathrm{O} 2 \Rightarrow \mathrm{CH} 2 \mathrm{O}+\mathrm{CO}+\mathrm{OH}$ \\
\hline R305 & $\mathrm{HCCO}+\mathrm{O} 2 \Rightarrow>\mathrm{OH}+2 \mathrm{CO}$ \\
\hline R377 & $\mathrm{CH} 3 \mathrm{O} 2 \mathrm{H} \Rightarrow \mathrm{CH} 3 \mathrm{O}+\mathrm{OH}$ \\
\hline R394 & $\mathrm{H} 2 \mathrm{O} 2(+\mathrm{M})<=>2 \mathrm{OH}(+\mathrm{M})$ \\
\hline R439 & $\mathrm{CH} 2 \mathrm{O}+\mathrm{O} \Rightarrow \mathrm{HCO}+\mathrm{OH}$ \\
\hline
\end{tabular}

The engine operating conditions are listed in Table 2. As can be seen, PPC experiments with PRF70 were conducted under a similar operating condition (around 5.4 bar IMEP) through three different injection strategies. During the experiments the engine speed was fixed at $1500 \mathrm{rpm}$, with the temperature of cooling water and lubricating oil kept at $85^{\circ} \mathrm{C}$ and $95^{\circ} \mathrm{C}$ respectively. The intake pressure was fixed at 1.8 bar and the EGR rate was fixed at $45 \%$. The total cyclic injection mass of PRF70 was $32 \mathrm{mg} /$ cycle, while PR varied from $0 \%$ to $50 \%$ by adjusting fuel mass distribution between intake-port injection and direct injection.

\section{Modeling Setup}

In the current study the PPC combustion process was simulated using a 3D CFD software CONVERGE [44] with PRF70 represented by nheptane and iso-octane. The fuel chemistry coupled was a reduced PRF mechanism consisting of 73 species and 296 reactions [50]. The sub-models used in the simulation, which had been validated in simulating the combustion process of a RCCI combustion engine [42, 43]. The renormalization group (RNG) $\mathrm{k}-\varepsilon$ model was adopted for the calculation of turbulence [51]. The Hiroyasu-NSC model empirical soot/oxidation model was applied to calculate the soot emission [52]. A Kelvin-Helmholtz Rayleigh-Taylor (KH-RT) model without breakup length was used to model the spray breakup process [46]. The no time counter (NTC) algorithm of Schmidt and Rutland was used to model droplet collisions [53], the Frossling correlation was used to model droplet evaporation [48]. In this study, a base mesh of $2 \mathrm{~mm}$ was used. To accurately simulate complex phenomena such as highvelocity flow, an adaptive mesh generation method using 3 as adaptive mesh refinement (AMR) scale was applied, with up to 770,000 grids which correspond to maximum and minimum grid sizes of $2 \mathrm{~mm}$ and $0.25 \mathrm{~mm}$, respectively. Figure 2 shows an example of the mesh generated. The simulation started from the intake valve closing (IVC) with the assumed homogeneous mixture of PRF70, air, and residue gas and completed at exhaust valve opening (EVO). The simulations were initialized with uniform concentrations, flow fields and temperatures at IVC.

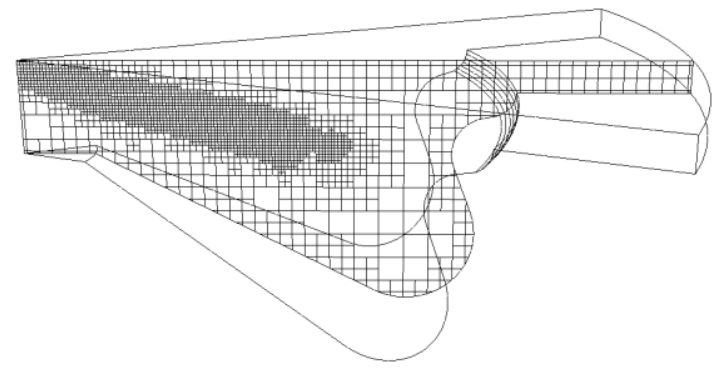

Figure 2. Computational grid.

The AHRR is derived from the first law of thermodynamics balance on the cylinder contents. It is essentially the chemical heat release rate minus the heat loss rate to the combustion chamber walls, and is given by:

$\mathrm{AHRR}={\frac{d Q}{d \theta_{\text {chem }}}}-{\frac{\mathrm{dQ}}{d \theta_{\text {wall }}}}=\frac{1}{\gamma-1} V \frac{\mathrm{dp}}{d \theta}+\frac{\gamma}{\gamma-1} P \frac{\mathrm{dV}}{d \theta}$

where $P$ is the average in-cylinder pressure, $V$ is the cylinder volume, and $\gamma$ is the ratio of specific heats for the in-cylinder gas mixture. According to Heywood's research, in this work, $\gamma$ was taken to be a constant of 1.3 when calculating the AHRR [54].

\section{Combustion visualization method}

To study the interaction mechanism between premixed fuel and direct injection fuel, a combustion visualization method was applied to examine the rate of production (ROP) of each species in each cell. The detailed information about the method can be referred in the Refs. [43]. For a specific species, the representative reactions accounting for its destruction and creation in each computational cell were also calculated and termed the representative destruction reaction (RDR) and creation reaction (RCR), respectively. By visualizing and

Page 3 of 11 
analyzing the RDRs and RCRs of the important species (such as $\mathrm{OH}$ and formaldehyde), some significant combustion characteristics can be explained. In the current work, the instantaneous species destruction pathway (ISDP) was calculated using the contribution of each reaction to the whole creation or destruction process for a specific species by:

$\beta_{i, j}=\frac{\omega_{i, j}}{\sum \omega_{i, j}}$

where the $\beta_{i, j}$ is the normalized creation/destruction rate of the ith species by the jth reaction, $\omega_{i, j}$ is the actual creation/destruction rate of the ith species by the jth reaction, and $\sum \omega_{i, j}$ is the total

creation/destruction rate of the ith species by all the reactions. Table 4 summarizes the major reactions identified by the RDR analyses in this work. Table 3 summarizes the major reactions identified by the RCR analyses in this work.

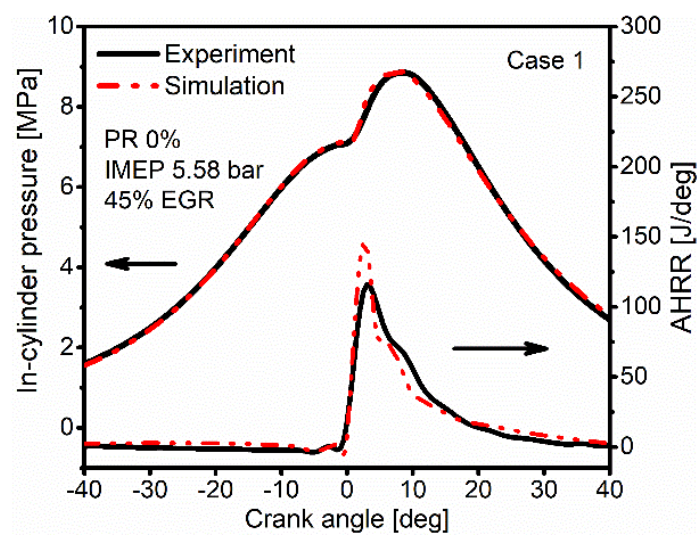

(a)

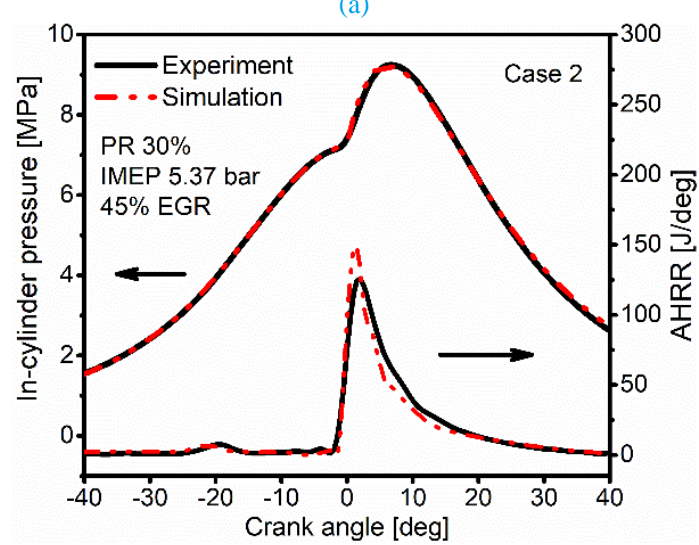

(b)

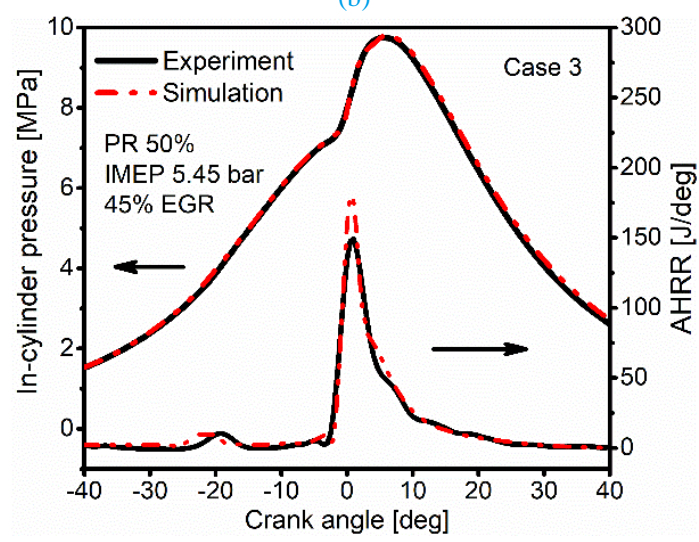

(c)

Figure 3. Comparisons of in-cylinder pressures and AHRRs between experiments and simulations. (a) $0 \% \mathrm{PFI}+\mathrm{DI}$ (b) $30 \% \mathrm{PFI}+\mathrm{DI}$ (c) $50 \% \mathrm{PFI}+\mathrm{DI}$ injection strategy.

Page 4 of 11

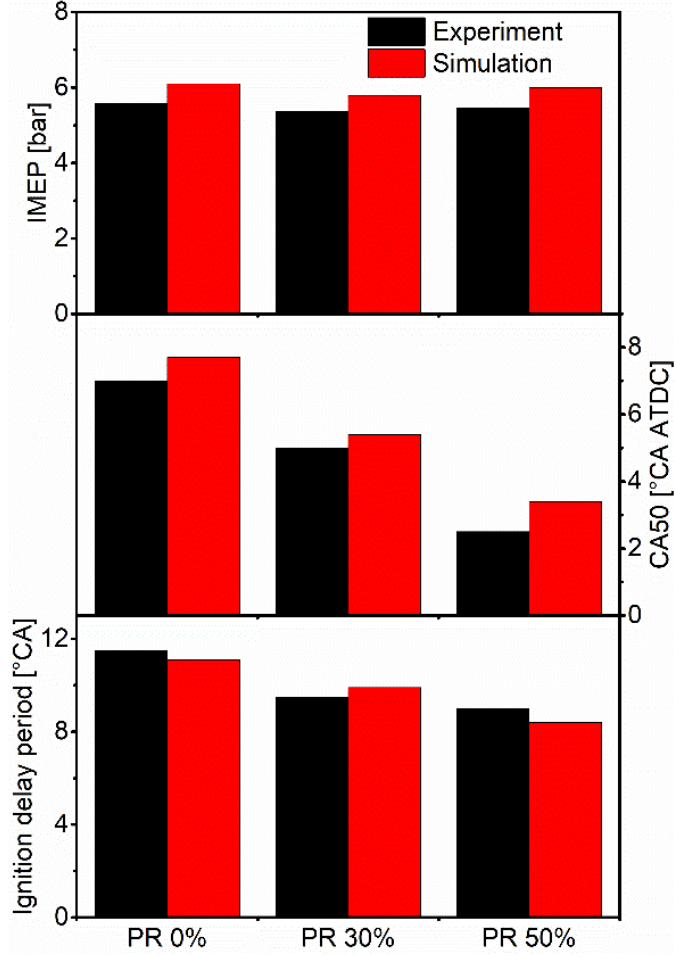

Figure 4. Comparisons of IMEP, CA50, and ignition delay period between experiments and simulations with three different injection strategies.

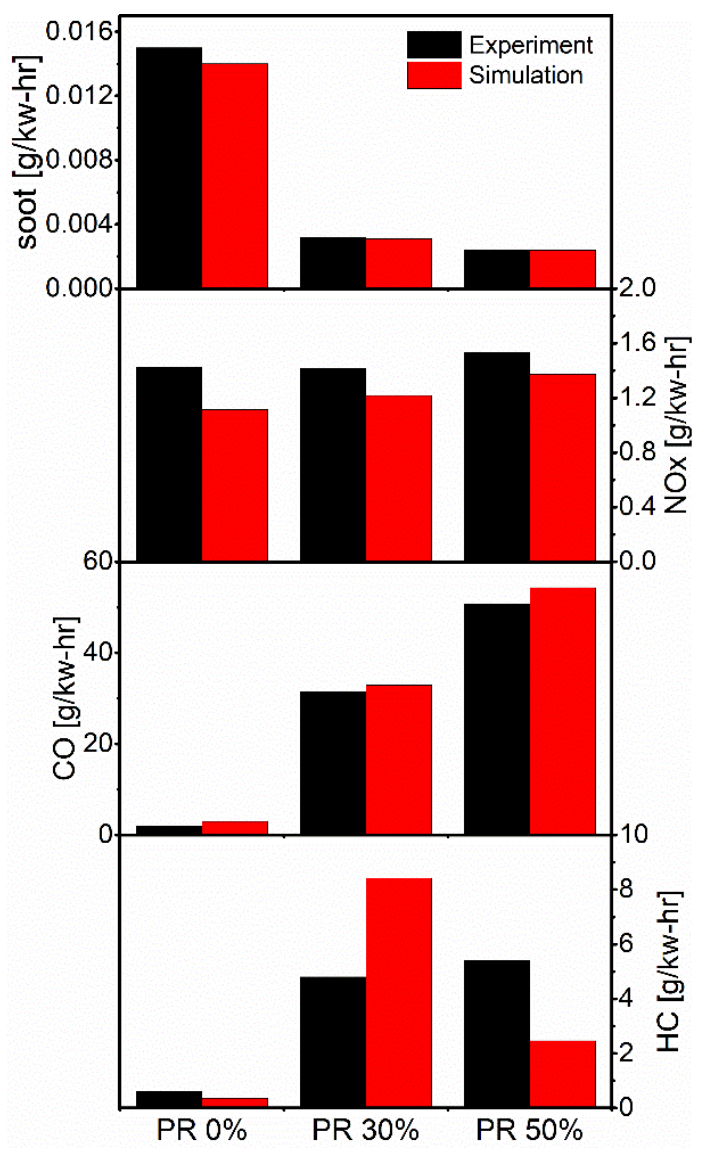

Figure 5. Comparisons of soot and NOx emissions between experiments and simulations with three different injection strategies. 


\section{Modeling validation}

The combustion model has been validated against the experimental combustion and emission results. As shown in Figure 3, the simulated cylinder pressure and AHRR were found to agree well with experimental data measured at PR0\%, PR30\% and PR50\%, respectively. Figure 4 compares the simulated IMEP, CA50 and ignition delay period with experimental data, and Figure 5 compares the soot, $\mathrm{NOx}, \mathrm{CO}$ and $\mathrm{HC}$ emissions. It can be seen that the CFD model could reasonably predict the trend of combustion and emissions at three operating conditions. Therefore, the CFD model is able to reasonably study the PPC combustion process by analyzing the physical and chemical process.

\section{Results and discussions}

Comparatively, as shown in Figure 4, The PR0\% case ignited slightly later than the PR30\% case, while the PR50\% case ignited much earlier. With the increase of PR, the ignition delay period decreased gradually. From the PR0\% case to the PR50\% case, the ignition delay decreased by $2.5 \mathrm{CA}$. That is to say, the intake-port injection fuel had an effect on the combustion ignition delay time.

It is known that the ignition delay time is related to the formation of hydroxyl $(\mathrm{OH})$. Thus, the mass fraction profiles of $\mathrm{OH}$ were investigated, as shown in Figure 6. With the increase of PR, the ignition time were gradually advanced. It can be seen that there was a close correspondence between the peak of $\mathrm{OH}$ mass fraction and the peak of AHRR. For the PR30\% case and PR50\% case, the OH mass fractions went up firstly, and then them went down during the NTC period. The first peak of $\mathrm{OH}$ is at $-23 \mathrm{CA}$. It's worth noting that the $\mathrm{OH}$ concentration of the PR30\% and the PR50\% case were much higher than that of the PR0\% case during whole ignition delay.

Wang et al. [55, 56] showed that the key species, such as C3KET21, $\mathrm{H}_{2} \mathrm{O}_{2}$ and $\mathrm{CH}_{3} \mathrm{O}_{2} \mathrm{H}$, produced through the low temperature reaction products of PRF can effectively shorten the ignition delay, which works by changing the $\mathrm{OH}$ concentration. Figure 7 shows the evolutions of the mass fraction of in-cylinder key species with three different injection strategies. With the increase of in-cylinder temperature, n-heptane and iso-octane began to be consumed by lowtemperature oxidation reactions. During the low-temperature oxidation, many key species that can promote ignition were produced. It can be seen that the concentrations of C3KET21, $\mathrm{H}_{2} \mathrm{O}_{2}$ and $\mathrm{CH}_{3} \mathrm{O}_{2} \mathrm{H}$ in the PR30\% and PR50\% cases were much higher than that in the PR0\% before the ignition time.

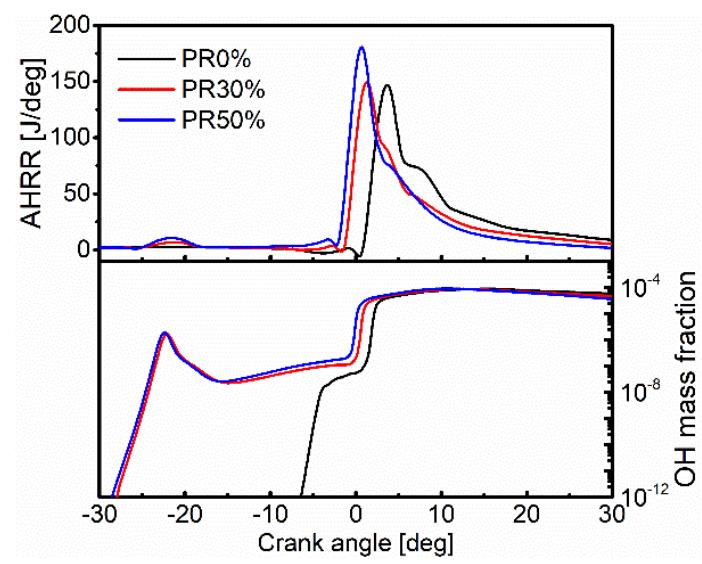

Figure 6. Evolutions of AHRRs and the mass fraction of $\mathrm{OH}$ with three different injection strategies.

Page 5 of 11

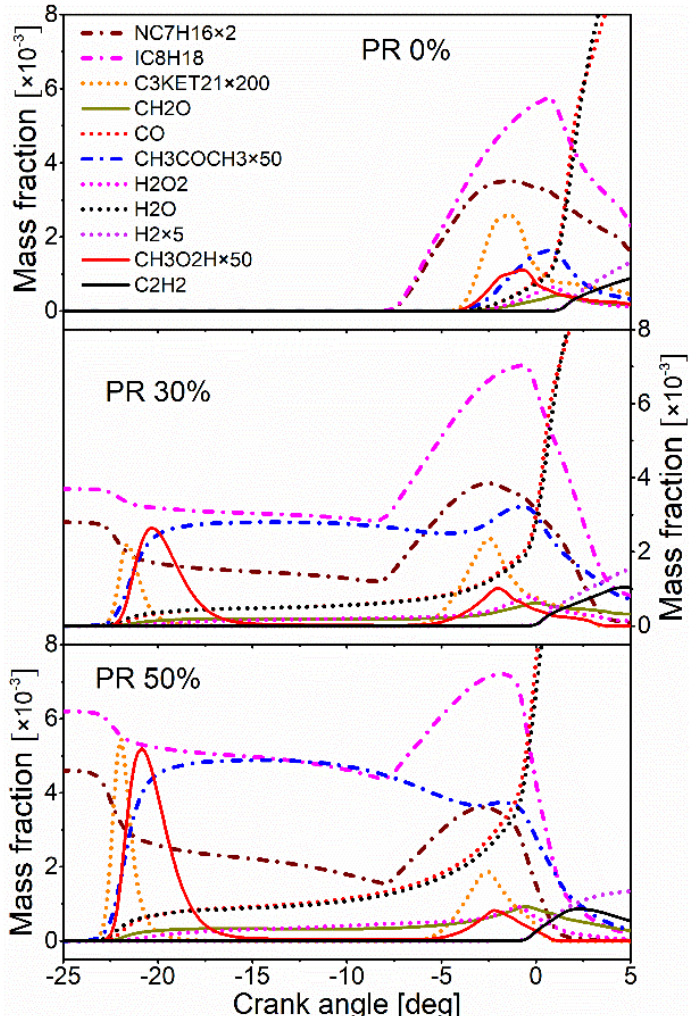

Figure 7. Evolutions of the mass fraction of in-cylinder key species with three different injection strategies. The key species include NC7H16, IC8H18, C3KET21, CH2O, CO, CH3COCH3, H2O2, H2O, H2, CH3O2H and $\mathrm{C} 2 \mathrm{H} 2$.

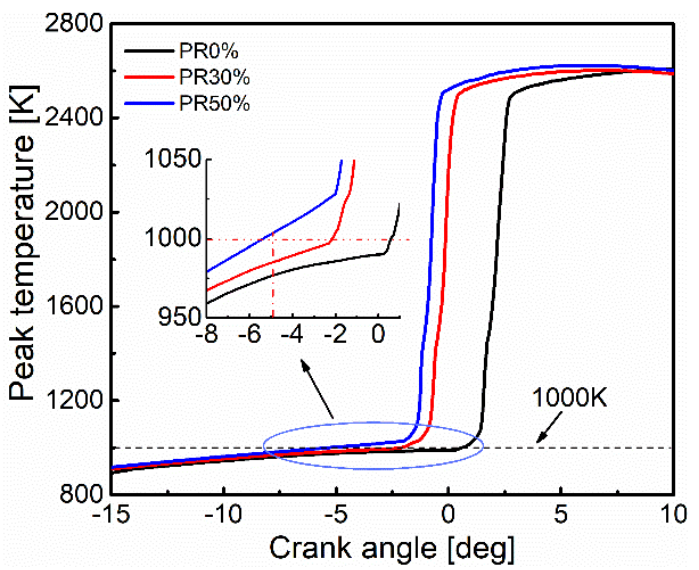

Figure 8 . The simulated peak temperature profiles with three different injection strategies.

Figure 8 shows the simulated peak temperature profiles. When the temperature is higher than $1000 \mathrm{~K}$, large $\mathrm{H}_{2} \mathrm{O}_{2}$ will start to decompose through $\mathrm{R} 394\left(\mathrm{H}_{2} \mathrm{O}_{2}(+\mathrm{M}) \Leftrightarrow \mathrm{OH}+\mathrm{OH}(+\mathrm{M})\right)$, which releases a large amount of heat and means the beginning of the high temperature ignition stage [57]. As shown in Figure 8, the peak temperature in the PR30\% and PR0\% were below $1000 \mathrm{~K}$ at $-5 \mathrm{CA}$, while the peak temperature in the PR50\% case was slightly above $1000 \mathrm{~K}$.

Thus, the reaction pathway analyses of the formations of $\mathrm{OH}$ at $-5 \mathrm{CA}$ were investigated. Figure 9 shows that $\mathrm{OH}$ can be produced both from n-heptane and iso-octane. Table 4 shows the ratio of different formation pathway of $\mathrm{OH}$ at $-5 \mathrm{CA}$ ATDC. It can be seen that the low temperature reaction sequence, the first oxygen addition-the first isomerization-the second oxygen addition-the second isomerization, accounts for most of the formation of $\mathrm{OH}$. The decompositions of the small hydroperoxides also contributed substantially to the formation of 
$\mathrm{OH}$. In the case of PR0\%, the second isomerization from $\mathrm{C}_{7} \mathrm{H}_{14} \mathrm{OOH}_{2}-$ $4 \mathrm{O}_{2}$ to NC7KET24 and the decomposition of NC7KET2 4 contributed $27.6 \%$ and $46.46 \%$ of $\mathrm{OH}$ formation respectively. The contribution of $\mathrm{AC}_{8} \mathrm{H}_{16} \mathrm{OOH}-\mathrm{B}$ to the formation of $\mathrm{OH}$ was just $12.13 \%$. It can be concluded that the low temperature oxidation reactions of n-heptane were key steps in producing $\mathrm{OH}$ in the case of PR0\%. While in the cases of PR30\% and PR50\%, because of the higher in-cylinder temperature, most of $\mathrm{OH}$ derived from the decomposition reaction of $\mathrm{H}_{2} \mathrm{O}_{2}$ that contributed $54.47 \%$ and $54.63 \%$ of $\mathrm{OH}$ formation respectively, from which it can be inferred that the temperature in most areas of the cylinder was close to $1000 \mathrm{~K}$, which can be confirmed in Figure 11. Besides, the oxidation reactions of $\mathrm{IC}_{4} \mathrm{H}_{7}$ contributed $31.95 \%$ and $33.84 \%$ of $\mathrm{OH}$ formation respectively, and the oxidation reaction of $\mathrm{IC}_{4} \mathrm{H}_{6} \mathrm{OH}$ contributed $19.08 \%$ and $22.22 \%$ of $\mathrm{OH}$ formation respectively, indicating that the oxidation of iso-octane also contributed to the production of $\mathrm{OH}$.

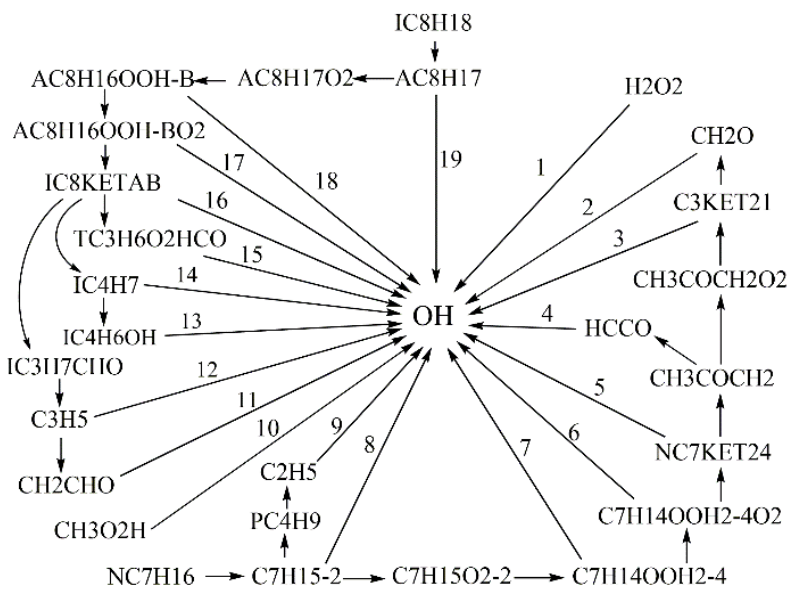

Figure 9. Reaction pathway analyses of the formation of $\mathrm{OH}$ at $-5 \mathrm{CA}$. (The number marked in the figure as the formation pathway of $\mathrm{OH}$, detailed description in table 4)

The absolute rate of production analysis of $\mathrm{OH}$ at $-5 \mathrm{CA}$ with three different PR are shown in Figure 10. The formation of $\mathrm{OH}$ was dominated by the decomposition reactions of NC7KET24, $\mathrm{C}_{7} \mathrm{H}_{14} \mathrm{OOH}_{2}-4 \mathrm{O}_{2}, \mathrm{AC}_{8} \mathrm{H}_{16} \mathrm{OOH}-\mathrm{B}$ and $\mathrm{TC}_{3} \mathrm{H}_{6} \mathrm{O}_{2} \mathrm{HCO}$ in the PR0\% case, while these reactions contributed very little to the formation of $\mathrm{OH}$ in the cases of PR30\% and PR50\%. On the contrary, in the cases of $\mathrm{PR} 30 \%$ and $\mathrm{PR} 50 \%$, the formation of $\mathrm{OH}$ was dominated by the decomposition of $\mathrm{H}_{2} \mathrm{O}_{2}$, and the oxidation reactions of $\mathrm{IC}_{4} \mathrm{H}_{7}$, $\mathrm{IC}_{4} \mathrm{H}_{6} \mathrm{OH}$ and $\mathrm{C}_{3} \mathrm{H}_{5}$, while these reactions contributed very little to the formation of $\mathrm{OH}$ in the PR0\% case. It can be seen that the formation of $\mathrm{OH}$ in the cases of PR30\% and PR50\% was exactly the opposite of that in PR0\% case at -5 CA.

To further figure out the differences of the formation of $\mathrm{OH}$ between three levels of PR, the combustion visualization method was applied to analyze the distribution of mass fraction and production rate of $\mathrm{OH}$ in cylinder. Figure 11 shows distributions of the mass fraction and production rate of $\mathrm{OH}$ under three different PR. Obviously, PR30\%

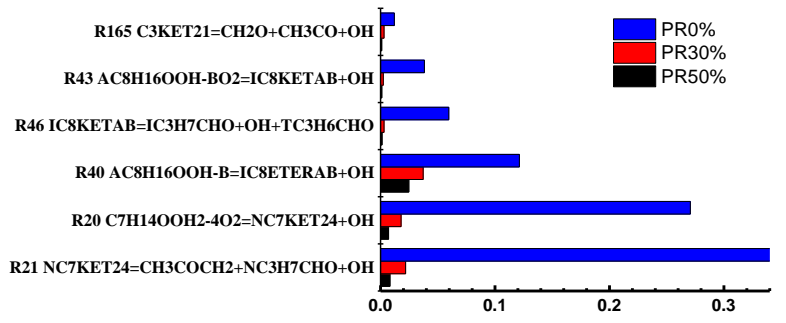

(a) and PR50\% had more widely distribution of $\mathrm{OH}$ mass fraction in the combustion chamber due to the oxidation of the homogeneous distributed fuel. Besides, all distributions of $\mathrm{OH}$ shows distinctive jet structures corresponding to nozzle holes, and the area around the spray was the area with the fastest $\mathrm{OH}$ formation rate. In addition, compared to $\mathrm{PR} 0 \%$, the formation of $\mathrm{OH}$ that derived from the oxidation of direct injection fuel was enhanced in the cases of PR30\% and PR50\%.

To further explain the difference about the formation of $\mathrm{OH}$ during ignition delay, Figure 12 evaluates the representative creative reactions of $\mathrm{OH}$ in each computational cell at $-5 \mathrm{CA}$, from which information relating to the interaction between port-injection and direct injection fuel can be observed. As shown in Figure 12, in the PR0\% the widest distribution of $\mathrm{OH}$ formation was predominantly controlled by the reaction $\mathrm{R} 21$, while in the cases of $\mathrm{PR} 30 \%$ and $\mathrm{PR} 50 \%$ that was predominantly controlled by the reactions of R394, R21 and R125. It can be seen RCRs dominated by R394 were distributed in the combustion chamber area outside the spray periphery. Combined with the absolute rate of production analysis of $\mathrm{OH}$ shown in Figure 10, it can be concluded that most of $\mathrm{OH}$ derived from the oxidation of port injection fuel. In addition, in the PR30\% and PR50\%, the formation of $\mathrm{OH}$ around spray periphery were dominated by the reactions $\mathrm{R} 21$ and $\mathrm{R} 125$, which indicated that premixed fuel from port injection promoted the formation of $\mathrm{OH}$ during the oxidation of direct injection fuel by R125.

Table 4. Ratio of different formation pathway of $\mathrm{OH}$ at $-5 \mathrm{CA}$.

\begin{tabular}{|c|c|c|c|c|}
\hline \multicolumn{2}{|c|}{ Reaction pathway } & \multirow{2}{*}{$\begin{array}{c}\text { PR0\% } \\
0.19\end{array}$} & \multirow{2}{*}{$\begin{array}{c}\text { PR30\% } \\
54.47\end{array}$} & \multirow{2}{*}{$\begin{array}{r}\text { PR50\% } \\
54.63\end{array}$} \\
\hline R394 & 1 & & & \\
\hline R439 & 2 & 0 & 0.42 & 0.56 \\
\hline R165 & 3 & 1.2 & 0.3 & 0.1 \\
\hline R305 & 4 & 0.14 & 2.46 & 1.85 \\
\hline R21 & 5 & 46.46 & 2.19 & 0.82 \\
\hline R20 & 6 & 27.06 & 1.79 & 0.7 \\
\hline R22 & 7 & 1.16 & 0.66 & 0.41 \\
\hline R5 & 8 & 0.02 & 0.22 & 0.16 \\
\hline R224 & 9 & 0.04 & 0.07 & 0.06 \\
\hline R377 & 10 & 0.22 & 2.94 & 2.31 \\
\hline R282 & 11 & 0.02 & 3.07 & 3.63 \\
\hline R178 & 12 & 0.01 & 4.59 & 5.2 \\
\hline $\mathrm{R} 125$ & 13 & 0.06 & 7.79 & 9.56 \\
\hline $\begin{array}{l}\text { R108 } \\
\text { R112 }\end{array}$ & 14 & 0.08 & 9.85 & 12.39 \\
\hline R97 & 15 & 1.14 & 0.27 & 0.14 \\
\hline R46 & 16 & 5.96 & 0.3 & 0.13 \\
\hline R43 & 17 & 3.83 & 0.24 & 0.11 \\
\hline R40 & 18 & 12.13 & 3.72 & 2.47 \\
\hline R31 & 19 & 0.02 & 0.6 & 0.57 \\
\hline \multicolumn{2}{|c|}{ Total } & 99.74 & 95.95 & 95.8 \\
\hline
\end{tabular}

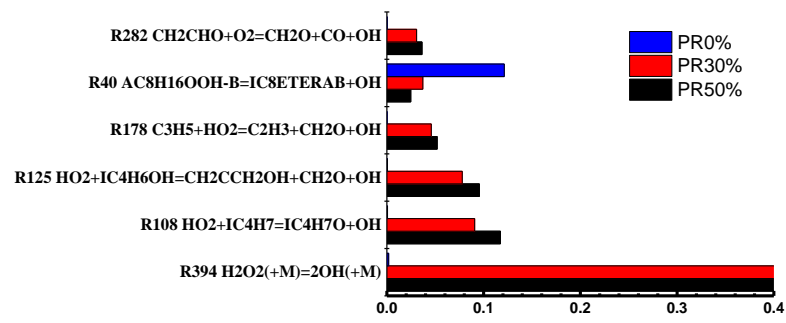

(b)

Figure 10. Absolute rate of production analysis of $\mathrm{OH}$ at -5 CA under two different standards: (a) based on PR0\%, (b) based on PR30\%.

Page 6 of 11 


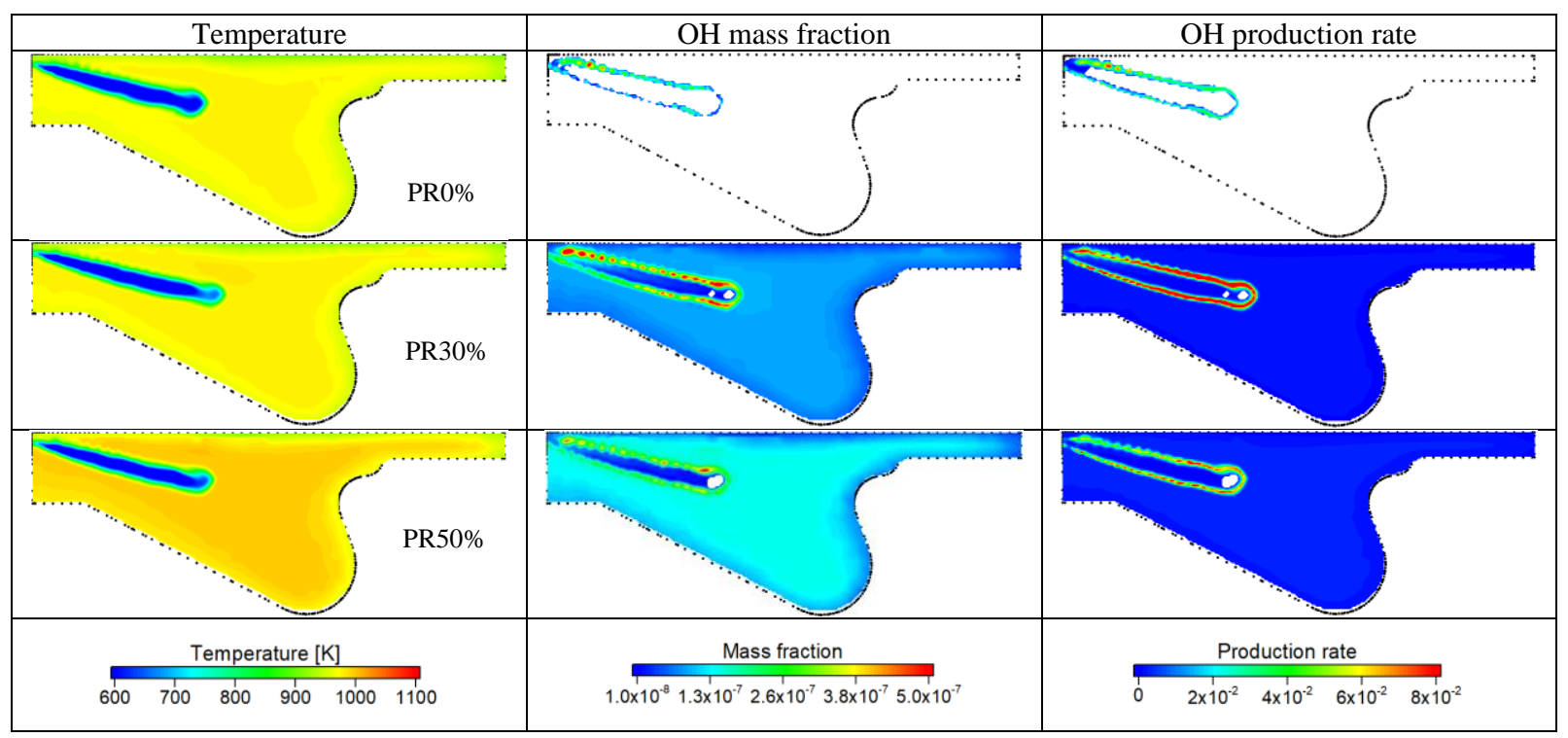

Figure 11. Distributions of temperature, mass fraction and production rate (mole/m3/s) of $\mathrm{OH}$ at $-5 \mathrm{CA}$ with three PR.

Figure 13 shows the Phi-T diagrams of $\mathrm{OH}$ RCRs at -5 CA. Combined with the RCR distribution of $\mathrm{OH}$ shown in Figure 12, in all cases, the reactions $\mathrm{R} 20$ and $\mathrm{R} 21$ dominated the formation of $\mathrm{OH}$ in the higher equivalence ratio regions corresponding to spray periphery, while the $\mathrm{R} 394$ only dominated $\mathrm{OH}$ formation in the regions with higher temperature and low equivalence ratio. Compared with the PR0\%, the reaction $\mathrm{R} 125$ dominated the formation of $\mathrm{OH}$ in the regions with higher equivalence ratio and lower temperature in the cases of PR30\% and PR50\%, while in the similar regions R97 dominated that in PR0\%, from which the results were consistent with the previous analysis.

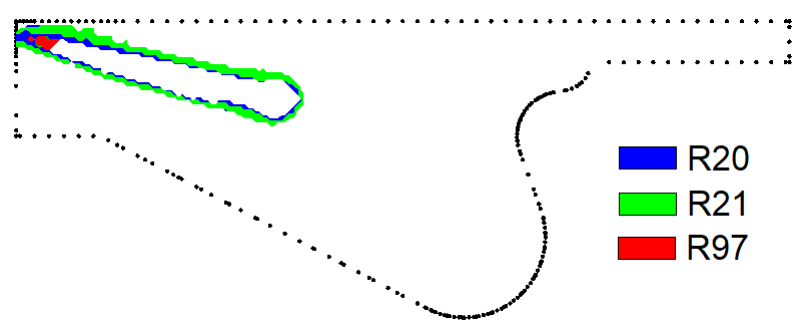

(a)

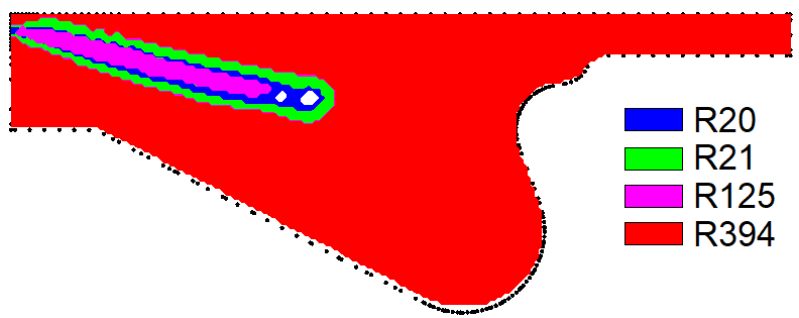

(b)

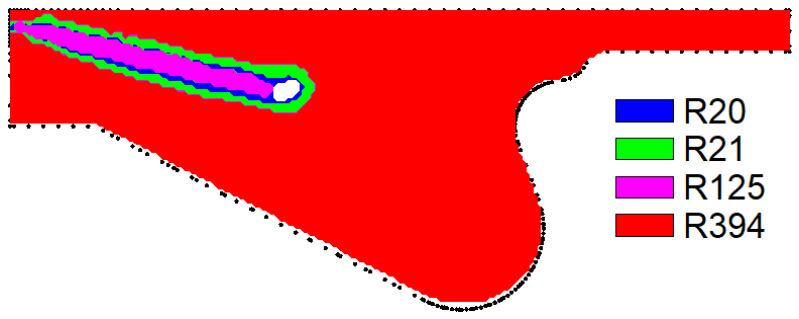

(c)

Figure 12. Distributions of RCR of OH at -5 CA with three PR: (a) PR0\%, (b) PR $30 \%$, (c) PR50\%.

Page 7 of 11

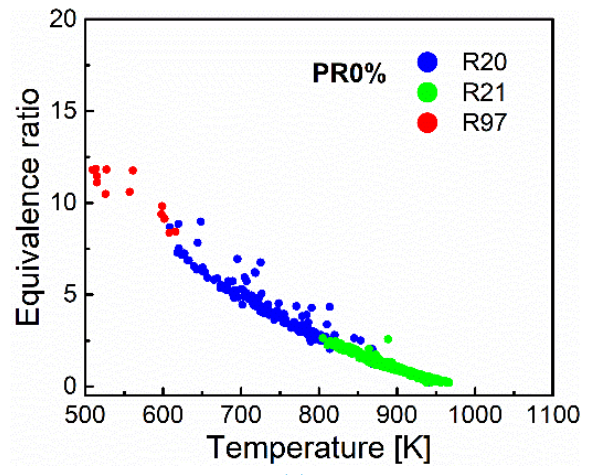

(a)

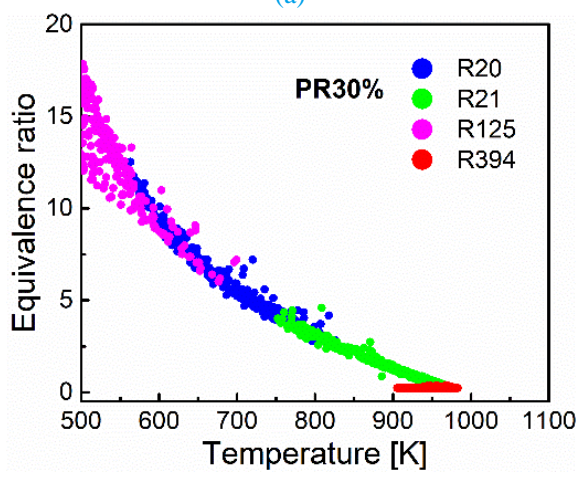

(b)

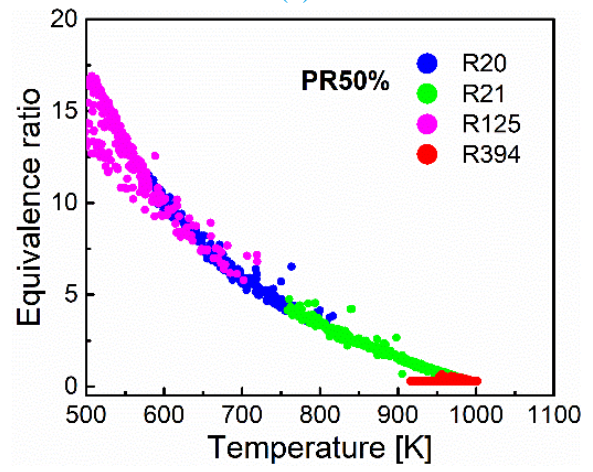

(c)

Figure 13. Phi-T diagrams of OH RCRs at -5 CA with three PR: (a) PR0\%, (b) PR30\%, (c) PR50\%. 
Figure 14 shows the ROP analyses for $\mathrm{OH}$ at $-5 \mathrm{CA}$. Combined with the RCR distribution of $\mathrm{OH}$ shown in Figure 12, in the case of PR0\%, it is noticed that although the reaction R97 dominated in some areas in the distribution of OH RCR, there was no R97 in the top 6 contributors of $\mathrm{OH}$ formation, and most of the $\mathrm{OH}$ was derived from reactions $\mathrm{R} 21$ and R20, all belonging to the significant low temperature consumption pathway of n-heptane. And in the cases of PR30\% and PR50\%, most of the $\mathrm{OH}$ was derived from the reaction $\mathrm{R} 394$, the second and the third largest amount were produced by the reactions R108 and R125, which means that $\mathrm{OH}$ mainly was produced by the oxidation of port-injection fuel.

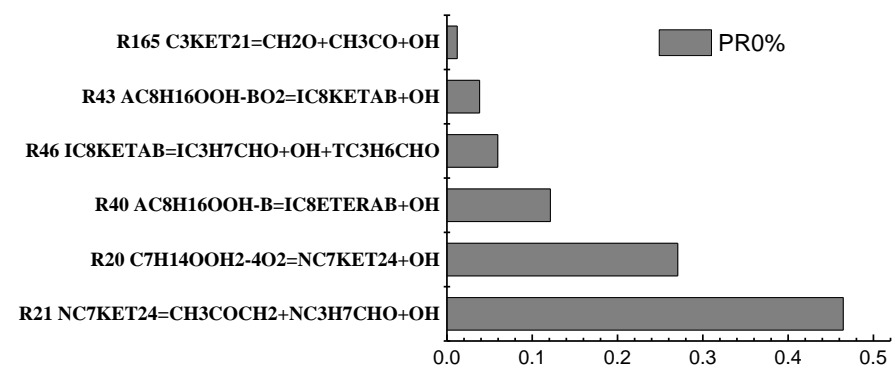

(a)

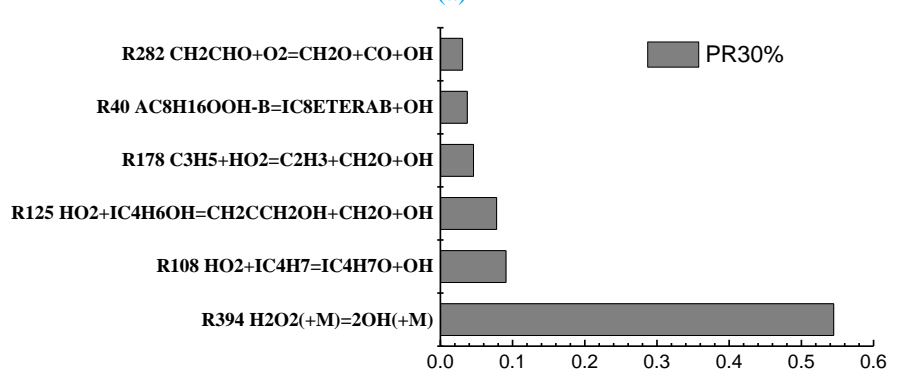

(b)

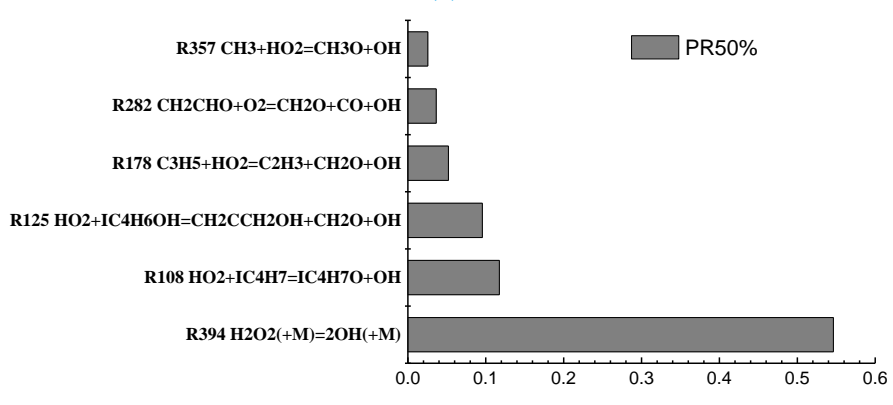

(c)

Figure 14. Distributions of RCR of OH at -5 CA with three PR: (a) PR0\%, (b) PR $30 \%$, (c) PR50\%.

\section{Conclusions}

In the current work, numerical investigations were conducted to study the ignition delay in PPC combustion achieved with PRF70 in a modified single cylinder heavy-duty diesel engine at low loads. Firstly, PPC experiments under three different operating conditions were used for model validation. Then, based on the combustion kinetics visualization method, comparison of the sensitivity of premixed fuel ratio on ignition delay and the formation of $\mathrm{OH}$ were studied. The major conclusions can be summarized as follows:

1. The modelling studies can reasonably predict the experimental combustion and emission results. It was found that the increase of PR can effectively decrease the ignition delay time of combustion through the increase of $\mathrm{OH}$ concentration due to the low temperature oxidation of premixed fuel.
2. Before the ignition, most of $\mathrm{OH}$ derived from the oxidation of port injection fuel in the cases of PR30\% and PR50\%.

3. The increase of $\mathrm{PR}$ can promote the formation of $\mathrm{OH}$ that derived from the oxidation of iso-octane and restrain that derived from the oxidation of n-heptane.

4. In the cases of PR30\% and PR50\%, the formation of OH outside the spray periphery were dominated by R394, while that in the spray periphery were predominantly controlled by the reactions R21 and R125. Premixed fuel from port injection changed the formation pathway of $\mathrm{OH}$ during the oxidation of direct injection fuel through the reaction R125.

\section{References}

[1] Musculus, M.P., Miles, P.C., and Pickett, L.M., "Conceptual models for partially premixed low-temperature diesel combustion,"Progress in Energy and Combustion Science 39(23):246-283, 2013, doi:10.1016/j.pecs.2012.09.001.

[2] Yao, M., Zheng, Z., and Liu, H., "Progress and recent trends in homogeneous charge compression ignition (HCCI) engines,"Progress in Energy and Combustion Science 35(5):398437, 2009, doi:10.1016/j.pecs.2009.05.001.

[3] Battin-Leclerc, F., "Detailed chemical kinetic models for the lowtemperature combustion of hydrocarbons with application to gasoline and diesel fuel surrogates,"Progress in Energy and Combustion Science 34(4):440-498, 2008, doi:10.1016/j.pecs.2007.10.002.

[4] Splitter, D. A., Hanson, R. M., Kokjohn, S. L., \& Reitz, R, "Improving engine performance by optimizing fuel reactivity with a dual fuel PCCI strategy. gen (NOx),"

[5] Lü, X.-C., Chen, W., and Huang, Z., "A fundamental study on the control of the HCCI combustion and emissions by fuel design concept combined with controllable EGR. Part 1. The basic characteristics of HCCI combustion,"Fuel 84(9):1074-1083, 2005, doi:10.1016/j.fuel.2004.12.014.

[6] Yu, R., Joelsson, T., Bai, X.S., and Johansson, B., "Effect of Temperature Stratification on the Auto-ignition of Lean Ethanol/Air Mixture in HCCI engine," doi:10.4271/2008-01$\underline{1669}$.

[7] Liu, H., Zheng, Z., Yao, M., Zhang, P. et al., "Influence of temperature and mixture stratification on HCCI combustion using chemiluminescence images and CFD analysis,"Applied Thermal Engineering 33-34:135-143, 2012, doi:10.1016/j.applthermaleng.2011.09.026.

[8] Liu, H., Zhang, P., Li, Z., Luo, J. et al., "Effects of temperature inhomogeneities on the HCCI combustion in an optical engine,"Applied Thermal Engineering 31(14-15):2549-2555, 2011, doi:10.1016/j.applthermaleng.2011.04.020.

[9] Lu, L., Najt, P.M., Kuo, T.-w., Sankaran, V. et al., “A fully integrated linear eddy and chemistry agglomeration method with detailed chemical kinetics for studying the effect of stratification on HCCI combustion,"Fuel 105:653-663, 2013, doi:10.1016/j.fuel.2012.09.031.

[10] Zheng, Z. and Yao, M., "Charge stratification to control HCCI: Experiments and CFD modeling with n-heptane as fuel," Fuel 88(2):354-365, 2009, doi:10.1016/j.fuel.2008.09.002.

[11] Leermakers, C., Bakker, P.C., Nijssen, B., Somers, L. et al., "Low octane fuel composition effects on the load range capability of

Page 8 of 11 
partially premixed combustion,"Fuel 135:210-222, 2014, doi:10.1016/j.fuel.2014.06.044.

[12] Kalghatgi, G.T., Hildingsson, L., Harrison, A.J., and Johansson, B., "Autoignition quality of gasoline fuels in partially premixed combustion in diesel engines,"Proceedings of the Combustion Institute 33(2):3015-3021, 2011, doi:10.1016/j.proci.2010.07.007.

[13] Lee, C.S., Lee, K.H., and Kim, D.S., “ "Experimental and numerical study on the combustion characteristics of partially premixed charge compression ignition engine with dual fuel $\downarrow$, ” Fuel 82(5):553-560, 2003, doi:10.1016/S0016-2361(02)00319-8.

[14] Jia, M., Li, Y., Xie, M., and Wang, T., "Numerical evaluation of the potential of late intake valve closing strategy for diesel PCCI (premixed charge compression ignition) engine in a wide speed and load range,"Energy 51:203-215, 2013, doi:10.1016/j.energy.2012.12.041.

[15] Musculus, M.P.B., "Multiple Simultaneous Optical Diagnostic Imaging of Early-Injection Low-Temperature Combustion in a Heavy-Duty Diesel Engine," doi:10.4271/2006-01-0079.

[16] Noehre, C., Andersson, M., Johansson, B., and Hultqvist, A., "Characterization of Partially Premixed Combustion," doi:10.4271/2006-01-3412.

[17] Lee, C.H. and Lee, K.H., "An Experimental Study on the Combustion and Emission Characteristics of a Stratified Charge Compression Ignition (SCCI) Engine,"Energy Fuels 21(4):19011907, 2007, doi:10.1021/ef060638h.

[18] Lee, K. and Lee, C., "An Experimental Study of the Extent of the Operating Region and Emission Characteristics of Stratified Combustion Using the Controlled Autoignition Method,"Energy Fuels 20(5):1862-1869, 2006, doi:10.1021/ef060037q.

[19] Yang, Y., Dec, J.E., Dronniou, N., and Sjöberg, M., “Tailoring HCCI heat-release rates with partial fuel stratification: Comparison of two-stage and single-stage-ignition fuels,"Proceedings of the Combustion Institute 33(2):3047-3055, 2011, doi:10.1016/j.proci.2010.06.114.

[20] Liu, H., Ma, S., Zhang, Z., Zheng, Z. et al., "Study of the control strategies on soot reduction under early-injection conditions on a diesel engine,"Fuel 139:472-481, 2015, doi:10.1016/i.fuel.2014.09.011.

[21] Liu, J., Shang, H., Wang, H., Zheng, Z. et al., "Investigation on partially premixed combustion fueled with gasoline and PODE blends in a multi-cylinder heavy-duty diesel engine,"Fuel 193:101-111, 2017, doi:10.1016/j.fuel.2016.12.045.

[22] Najafabadi, M.I., Egelmeers, L., Somers, B., Deen, N. et al., "The influence of charge stratification on the spectral signature of partially premixed combustion in a light-duty optical engine,"Appl. Phys. B 123(4):246, 2017, doi:10.1007/s00340017-6688-9.

[23] Atef, N., Badra, J., Jaasim, M., Im, H.G. et al., "Numerical investigation of injector geometry effects on fuel stratification in a GCI engine,"Fuel 214:580-589, 2018, doi:10.1016/i.fuel.2017.11.036.

[24] Yang, D.-b., Wang, Z., Wang, J.-X., and Shuai, S.-j., "Experimental study of fuel stratification for HCCI high load extension,"Applied Energy 88(9):2949-2954, 2011, doi:10.1016/j.apenergy.2011.03.004.

[25] Lu, X., Shen, Y., Zhang, Y., Zhou, X. et al., "Controlled threestage heat release of stratified charge compression ignition (SCCI)

Page 9 of 11 combustion with a two-stage primary reference fuel supply," Fuel 90(5):2026-2038, 2011, doi:10.1016/j.fuel.2011.01.026.

[26] Wu, H.-W., Wang, R.-H., Chen, Y.-C., Ou, D.-J. et al., "Influence of port-inducted ethanol or gasoline on combustion and emission of a closed cycle diesel engine,"Energy 64:259-267, 2014, doi:10.1016/j.energy.2013.11.027.

[27] Qian, Y., Ouyang, L., Wang, X., Zhu, L. et al., "Experimental studies on combustion and emissions of RCCI fueled with nheptane/alcohols fuels,"Fuel 162:239-250, 2015, doi:10.1016/j.fuel.2015.09.022.

[28] Yang, B., Wang, H., Yao, M., Zheng, Z. et al., "Experimental Investigation on the Effects of Injection Strategy on Combustion and Emission in a Heavy-Duty Diesel Engine Fueled with Gasoline," International Powertrains, Fuels \& Lubricants Meeting, SAE Technical Paper Series, OCT. 16, 2017, SAE International400 Commonwealth Drive, Warrendale, PA, United States, 2017.

[29] Kalghatgi, G.T., Risberg, P., and Angstrom, H.-E., "Partially PreMixed Auto-Ignition of Gasoline to Attain Low Smoke and Low NOx at High Load in a Compression Ignition Engine and Comparison with a Diesel Fuel," doi:10.4271/2007-01-0006.

[30] Goyal, H., Kook, S., Hawkes, E., Chan, Q.N. et al., "Influence of Engine Speed on Gasoline Compression Ignition (GCI) Combustion in a Single-Cylinder Light-Duty Diesel Engine," WCX $X^{\mathrm{TM}}$ 17: SAE World Congress Experience, SAE Technical Paper Series, APR. 04, 2017, SAE International400 Commonwealth Drive, Warrendale, PA, United States, 2017.

[31] Goyal, H., Kook, S., and Ikeda, Y., "The influence of fuel ignition quality and first injection proportion on gasoline compression ignition (GCI) combustion in a small-bore engine,"Fuel 235:1207-1215, 2019, doi:10.1016/j.fuel.2018.08.090.

[32] Jain, A., Singh, A.P., and Agarwal, A.K., "Effect of split fuel injection and EGR on NOx and PM emission reduction in a low temperature combustion (LTC) mode diesel engine,"Energy 122:249-264, 2017, doi:10.1016/j.energy.2017.01.050.

[33] Liu, H., Ma, G., Ma, N., Zheng, Z. et al., "Effects of charge concentration and reactivity stratification on combustion and emission characteristics of a PFI-DI dual injection engine under low load condition,"Fuel 231:26-36, 2018, doi:10.1016/j.fuel.2018.05.027.

[34] Dempsey, A.B., Curran, S.J., and Wagner, R.M., “A perspective on the range of gasoline compression ignition combustion strategies for high engine efficiency and low NOx and soot emissions: Effects of in-cylinder fuel stratification,'International Journal of Engine Research 17(8):897-917, 2016, doi: $10.1177 / 1468087415621805$.

[35] Kalghatgi, G.T., Risberg, P., and Ångström, H.-E., “Advantages of Fuels with High Resistance to Auto-ignition in Late-injection, Low-temperature, Compression Ignition Combustion," doi:10.4271/2006-01-3385.

[36] Kalghatgi, G., Hildingsson, L., and Johansson, B., "Low NOx and Low Smoke Operation of a Diesel Engine Using Gasolinelike Fuels,"Journal of Engineering for Gas Turbines and Power 132(9):303, 2010, doi:10.1115/1.4000602.

[37] Hildingsson, L., Kalghatgi, G., Tait, N., Johansson, B. et al., "Fuel Octane Effects in the Partially Premixed Combustion Regime in Compression Ignition Engines," doi:10.4271/2009-01$\underline{2648}$. 
[38] Tang, Q., Liu, H., Li, M., Yao, M. et al., "Study on ignition and flame development in gasoline partially premixed combustion using multiple optical diagnostics,"Combustion and Flame 177:98-108, 2017, doi:10.1016/j.combustflame.2016.12.013.

[39] Goyal, H., Zhang, Y., Kook, S., Kim, K.S. et al., "Low- to HighTemperature Reaction Transition in a Small-Bore Optical Gasoline Compression Ignition (GCI) Engine,"SAE Int. J. Engines 12(5), 2019, doi:10.4271/03-12-05-0031.

[40] Li, Y., Li, H., Guo, H., Wang, H. et al., "A numerical study on the chemical kinetics process during auto-ignition of n-heptane in a direct injection compression ignition engine,"Applied Energy 212:909-918, 2018, doi:10.1016/j.apenergy.2017.12.067.

[41] Li, Y., Guo, H., and Li, H., "Evaluation of Kinetics Process in CFD Model and Its Application in Ignition Process Analysis of a Natural Gas-Diesel Dual Fuel Engine," WCX ${ }^{\mathrm{TM}}$ 17: SAE World Congress Experience, SAE Technical Paper Series, APR. 04, 2017, SAE International400 Commonwealth Drive, Warrendale, PA, United States, 2017.

[42] Liu, X., Kokjohn, S., Li, Y., Wang, H. et al., "A numerical investigation of the combustion kinetics of reactivity controlled compression ignition (RCCI) combustion in an optical engine,"Fuel 241:753-766, 2019, doi:10.1016/j.fuel.2018.12.068.

[43] Liu, X., Kokjohn, S., Wang, H., and Yao, M., “A comparative numerical investigation of reactivity controlled compression ignition combustion using Large Eddy Simulation and ReynoldsAveraged Navier-Stokes approaches,"Fuel 257:116023, 2019, doi:10.1016/j.fuel.2019.116023.

[44] Cracknell, R.F., Ariztegui, J., Dubois, T., Hamje, H. et al., "Modelling a Gasoline Compression Ignition (GCI) Engine Concept," SAE 2014 World Congress \& Exhibition, SAE Technical Paper Series, APR. 08, 2014, SAE International400 Commonwealth Drive, Warrendale, PA, United States, 2014.

[45] Das Adhikary, B., Ra, Y., Reitz, R.D., and Ciatti, S., "Numerical Optimization of a Light-Duty Compression Ignition Engine Fuelled With Low-Octane Gasoline," SAE 2012 World Congress \& Exhibition, SAE Technical Paper Series, APR. 24, 2012, SAE International400 Commonwealth Drive, Warrendale, PA, United States, 2012.

[46] Shi, Y., Wang, Y., and REITZ, R.D., "Computational Fluid Dynamic Modelling a Heavy-Duty Compression-Ignition Engine Fuelled with Diesel and Gasoline-Like Fuels,'International Journal of Engine Research 11(5):355-373, 2010, doi:10.1243/14680874JER537.

[47] Dempsey, A.B., Curran, S.J., and Wagner, R.M., "A perspective on the range of gasoline compression ignition combustion strategies for high engine efficiency and low NOx and soot emissions: Effects of in-cylinder fuel stratification,'International Journal of Engine Research 17(8):897-917, 2016, doi: $10.1177 / 1468087415621805$.

[48] Liu, X., Tong, L., Wang, H., Zheng, Z. et al., "Experimental and Modelling Investigations of the Gasoline Compression Ignition Combustion in Diesel Engine," WCX ${ }^{\mathrm{TM}}$ 17: SAE World Congress Experience, SAE Technical Paper Series, APR. 04, 2017, SAE International400 Commonwealth Drive, Warrendale, PA, United States, 2017.

[49] Liu, X., Wang, H., Zhang, Y., and Yao, M., “A Numerical Investigation on the Chemical Kinetics Process of a Reacting n Dodecane Spray Flame under Compression Ignition Combustion

Page 10 of 11
Condition,"Energy Fuels 33(11):11899-11912, 2019, doi:10.1021/acs.energyfuels.9b02725.

[50] Wang, H., Yao, M., and Reitz, R.D., "Development of a Reduced Primary Reference Fuel Mechanism for Internal Combustion Engine Combustion Simulations,"Energy Fuels 27(12):78437853, 2013, doi:10.1021/ef401992e.

[51] HAN, Z. and REITZ, R.D., "Turbulence Modeling of Internal Combustion Engines Using RNG $\kappa-\varepsilon$ Models,"Combustion Science and Technology 106(4-6):267-295, 1995, doi:10.1080/00102209508907782.

[52] Author, U., "Proceedings of the Fifth Conference on Carbon," Elsevier Science, Burlington, ISBN 9780080097077, 1962.

[53] Schmidt, D.P. and Rutland, C.J., "A New Droplet Collision Algorithm,"Journal of Computational Physics 164(1):62-80, 2000, doi:10.1006/jcph.2000.6568.

[54] Heywood, J.B., "Internal combustion engine fundamentals," ISBN 0-07-028637-X, 1988.

[55] Wang, Y., Wei, L., and Yao, M., "Theoretical Investigation of the Combustion of PRF90 under the Flexible Cylinder Engine Mode: The Effects of Cooling Strategies on the Mode,"Energy Fuels 31(12):13273-13281, 2017, doi:10.1021/acs.energyfuels.7b02216.

[56] Wang, Y., Wang, H., and Yao, M., "Effects of low-temperature reforming products of PRF50 on combustion and emission characteristics in an HCCI engine,"Applied Thermal Engineering 151:451-458, 2019, doi:10.1016/j.applthermaleng.2019.01.088.

[57] Zádor, J., Taatjes, C.A., and Fernandes, R.X., "Kinetics of elementary reactions in low-temperature autoignition chemistry,"Progress in Energy and Combustion Science 37(4):371-421, 2011, doi:10.1016/j.pecs.2010.06.006.

\section{Contact Information}

Zunqing Zheng

State Key Laboratory of Engines Tianjin University No.92 Weijin Road Nankai District, Tianjin, 300072, P.R.China. Email: zhengzunqing@tju.edu.cn

\section{Acknowledgments}

The authors would like to acknowledge the financial support provided by the project of National Key R\&D Program of China (2017YFE0102800) and the National Natural Science Found of China (NSFC) through its Projects of 51576138.

\section{Definitions/Abbreviations}

$\begin{array}{ll}\text { ATDC } & \text { After top dead center } \\ \text { AHRR } & \text { Apparent heat release rates } \\ \text { CFD } & \text { Computational fluid dynamic } \\ \text { EVO } & \text { Exhaust valve open } \\ \text { IVC } & \text { Intake valve closing } \\ \text { IMEP } & \text { Indicated mean effective pressure } \\ \text { LTC } & \text { Low temperature combustion } \\ \text { PPC } & \text { Partially premixed combustion } \\ \text { PPCI } & \text { Premixed charge compression ignition } \\ \text { PR } & \text { Premixed ratio }\end{array}$


PRF

RCR

RDR
Primary reference fuel

Representative creation reaction

Representative destruction reaction
ROP

SOI
Rate of production

Start of injection

Page 11 of 11 